\title{
PERWUJUDAN WAWASAN NUSANTARA SEBAGAI SATU KESATUAN POLITIK,EKONOMI,SOSIAL BUDAYA DAN HANKAM
}

\author{
ARTHA DWI SHAFIRA PAWESTRI \\ S1 FARMASI \\ IIK STRADA INDONESIA \\ Safuraarta664@gmail.com
}

\begin{abstract}
ABSTRAK
Indonesia merupakan salah satu negara kepulauan di dunia. Atas dasar inilah dikembangkan geopolitik nasional Wawasan Nusantara. Wawasan Nusantara berarti cara pandang Indonesia tentang diri dan lingkungan berdasarkan ide nasional yang dilandasi Pancasila dan UUD Negara Republik Indonesia Tahun 1945. Wawasan Nusantara juga diartikan sebagai cara pandang dan sikap bangsa Indonesia mengenai diri dan lingkungannya. Dengan mengutamakan Persatuan dan Kesatuan bangsa serta Kesatuan wilayah dalam menyelenggarakan kehidupan bermasyarakat, berbangsa dan bernegara.

Wawasan Nusantara dalam kehidupan berbangsa yang mencakup kehidupan politik, ekonomi, sosial budaya dan pertahanan keamanan harus tercermin dalam pola pikir, pola sikap, dan pola tindak senantiasa mengutamakan kepentingan bangsa dan negara kesatuan Republik Indonesia di atas kepentingan pribadi dan golongan. Dengan demikian wawancara menjadi nilai yang menjiwai segenap peraturan perundang-undangan yang berlaku pada setiap dan strata di seluruh wilayah negara, sehingga menggambarkan sikap dan perilaku, paham serta semangat kebangsaan atau nasionalisme yang tinggi yang merupakan identitas atau jati diri bangsa Indonesia.
\end{abstract}

\section{- TINJAUAN PUSTAKA}

Wawasan nusantara terdiri dari unsur-unsur dasar, asas, arah pandang, fungsi, sasaran implementasi,soaialisasi serta tantangan implementasi. Wawasan nusantara dalam kehidupan berbangsa dan bernegara mencakup berbagai aspek yaitufalsafah pancasila, pembangunan nasional, satu kesatuan politik, satu kesatuan ekonomi, satukesatuan sosial dan budaya, serta satu kesatuan pertahanan keamanan dan luas wilayah Indonesia. 


\section{- LATAR BELAKANG}

Menurut Prof.Dr.Wan, Wawasan Nusantara adalah cara pandang bangsa Indonesia mengenai diri dan tanah airnya sebagai Negara Kepulauan dengan semua aspek kehidupan yang beragam.

Menurut kelompok kerja LEMHANAS 1999, Wawasan Nusantara adalah cara pandang dan sikap bangsa Indonesia mengenai diri dan lingkungannya yang beragam dan bernilai strategis dengan mengutamakan persatuan dan kesatuan bangsa dan kesatuan wilayah dalam menyelenggarakan kehidupan bermasyarakat, berbangsa dan bernegara untuk mencapai tujuan nasional.

Dalam pandangan lain, hakikat wawasan nusantara dapat diartikan sebagai keutuhan nusantara, yang merupakan cara pandang secara komprehensif terhadap lingkup nusantara dalam mewujudkan kepentingan nasional. Hal ini dilakukan oleh setiap warga negara termasuk aparat negara.

Perwujudan wawasan nusantara dalam kehidupan berbangsa dan bernegara merupakan salah satu proses pendewasaan pendirian manusia secara sistematis, dalam menjalani kehidupan secara bertanggung jawab dan berani mengambil keputusan serta tindakan yang bijaksana sekaligus berani menanggung berbagai konsekuensi yang ditimbulkan dalam kehidupan bermasyarakat. Dalam perkembangan dunia sekarang ini banyak dijumpai berbagai macam sikap dan tingkah laku yang kurang bahkan sangat merugikan masyarakat, hal ini juga dipengaruhi dengan kurangnya pengetahuan atau wawasan tentang bagaimana hidup berbangsa dan bernegara yang, baik, sebagaimana tercantum dalam butir-butir Pancasila dan UUD 1945.

Sebagai manusia yang mengerti akan wawasan nusantara juga diajarkan bagaimana cara agar dapat menerapkannya dalam masyarakat, tetapi yang terjadi justru sebaliknya, yang sebenarnya sudah mengetahui hal tersebu justru menjadi pemicu terjadinya hal tersebut. Sehingga apa yang dipelajari menjadi sia-sia. Oleh karena itu wawasan nasional indonesia tidak disalah artikan oleh masing-masing individu, tetapi dimengerti dan dijalankan demi terciptanya persatuan dan kesatuan dengan tidak menghilangkan ciri, sifat dan karakter ke bhinekaan sebagai unsur pembentuk bangsa yakni suku-suku bangsa, etnis, golongan dan daerah itu sendiri. 


\section{- PEMBAHASAN}

1) Pengertian wawasan nusantara

Wawasan Nusantara adalah cara pandang dan sikap bangsa Indonesia diri dan lingkungannya, dengan mengutamakan persatuan dan kesatuan wilayah dalam penyelenggaraan kehidupan bermasyarakat, berbangsa, dan bernegara yang bersumber pada Pancasila dan berdasarkan Pembukaan UUD 1945.

2) Unsur-unsur dasar wawasan nusantara

a. Wadah ( contour)

Wadah kehidupan berbangsa dan bernegara meliputi seluruh wilayah Indonesia yang memiliki kekayaan kekayaan alam dan penduduk dengan aneka ragam budaya. Bangsa Indonesia memiliki organisasi kenegaraan yang merupakan wadah berbagai kegiatan kenegaraan dan wujud infrastuktur politik. Sementara itu, wadah dalam kehidupan bermasyarakat adalah berbagai dalam wujud infrastuktur politik.

b. Isi ( content )

Isi adalah aspirasi bangsa yang berkembang di masyarakat dan cita-cita serta tujuan nasional yang terdapat dalam pembukaan UUD 1945. Untuk menciptakan hal tersebut, bangsa Indonesia harus mampu menciptakan persatuan dan kesatuan bangsa dalam kebhinekaan. Isi menyangkut dua hal yang esensial.

c. Tata laku ( conduct)

Tata laku merupakan hasil interaksi dari wadah dan isi, yang terdiri dari tata laku bathiniah dan lahiriah. Tata laku bathiniah mencerminkan jiwa, semangat, dan mentalitas yang baik ari bangsa Indonesia. Sedangkan tata laku lahiriah tercermin dalam tindakan, operbuatan dan perilaku bangsa Indonesia. Kedua hal tersebut akan mencerminkan identitas jati diri bangsa dan kepribadian bangsa.

3) Faktor-faktor yang Mempengaruhi Wawasan Nusantara

1. Wilayah (Geografi)

a. Asas Kepulauan (Archipelagic Principle)

Kata Archipelago dan Archipelagic berasal dari kata italia Archipelagos. Akar katanya adalah Archi berarti terpenting, terutama, dan Pelagos berartilaut atau wilayah lautan. Jadi, Archipelago dapat diartikan sebagai wilayah lautan terpenting dengan pulau-pulau didalamnya. Lahirnya asas Archipelago mengandung pengertian bahwa pulau-pulau tersebut selalu dalam kesatuan utuh, sementara tempat unsur perairan atau lautan antara pulau-pulau berfungsi sebagai unsur penghubung dan bukan unsur pemisah. 
b. Kepulauan Indonesia

Bagian wilayah indische archipel yang dikuasai oleh belanda dinamakan Neterlandsch Oos Indishe Archipelago. Itulah wilayah jajahan Belanda yang kemudian menjadi wilayah negara Republik Indonesia. Bangsa Indonesia sangat mencintai nama Indonesia" meskipun bukan dari bahasanya sendiri. Dalam bahasa Yunani "Indo" berarti India dan "nesos" berarti pulau. Sebutan "Indonesia” merupakan ciptaan ilmuan J.R. Logan dalam Journal of the Indian Archipelago and East Asia (1850). Kemudian sejak proklamasi kemerdekaan RI 17 Agustus 1945, Indonesia menjadi nama resmi negara dan bangsa Indonesia sampai sekarang.

c. Konsepsi tentang Wilayah Lautan

Dalam perkembangan hukum laut internasional dikenal beberapa mengenai pemilikan dan penggunaan wilayah laut sebagai berikut :

1. Res Nullius, menyatakan bahwa laut itu tidak ada yang memilikinya.

2. Res Cimmunis, menyatakan bahwa laut adalah milik masyarakat dunia karena itu tidak dapat dimiliki oleh masing-masing negara.

3. Mare Liberum, menyatakan bahwa wilayah laut adalah bebas untuk semua bangsa.

4. Mare Clausum ( The Right and Dominion Of the Sea), menyatakan bahwa laut sepanjang laut saja yang dapat dimiliki oleh suatu negara sejauh yang dapat dikuasai dari darat (waktu itu kira- kira 3 mil).

5. Archipelagic State Pinciples (asas Negara Kepulauan) yang menjadikan dasar dalam Konvensi PBB tentang hukum laut.

d. Karakteristik Wilayah Nusantara

Nusantara berarti Kepulauan Indonesia yang terletak di antara benua Asia dan benua Australia dan diantara samudra Pasifik dan samudra Indonesia, yang terdiri dari 17.508 pulau besar maupu kecil. Jumlah pulau yang sudah memiliki nama adalah 6.044 buah. Kepulauan Indonesia terletak pada batas-batas astronomi sebagai berikut :Utara : $\pm 6^{\circ} 08^{\prime \prime}$ LU Selatan: $\pm 11^{\circ}$ 15" LS Barat: $\pm 94^{\circ} 45^{\prime \prime}$ BT Timur: $\pm 141^{\circ} 05^{\prime \prime B T ~ J a r a k ~ u t a r a ~-~ s e l a t a n ~ s e k i t a r ~}$ 1.888 Kilometer, sedangakan jarak barat - timur sekitar 5.110 Kilometer. Luas wilayah Indonesia seluruhnya adalah5.193.250 km2,yang terdiri dari daratan seluas 2.027.087 km2 dan perairan1273.166.163 km2. Luas wilayah daratan Indonesia jika dibandingkandengan negara - negara Asia Tenggara merupakan yang terluas. 
2. Geostrategi

Strategi adalah politik dalam pelaksanaan, yaitu upaya bagaimana mencapaitujuan atau sasaran yang ditetapkan sesuai dengan keinginan politik.Strategi juga dapat merupakan ilmu, yang langkah - langkahnya selalu berkaitan dengan data dan fakta yang ada. Sebagai contoh pertimbangan geostrategis untuk negara dan bangsa Indonesia adalah kennyataan posisi silang Indonesia dari berbagai aspek, di samping aspek geografi juga aspek aspek demografi, ideologi, politik, ekonomi, sosial budaya dan Hankam.

\section{- KESIMPULAN}

Secara garis besar wawasan nusantara adalah cara pandang dan sikap untuk menentukan kehidupanberbangsa dan bernegara yang berdasarkan pada ideologi bangsa itu sendiri.

Wawasan nusantara di indonesia berdasarkan filsafat pancasila, pembangunan nasional, kesatanpolitik, kesatuan ekonomi, sosial dan budaya, kesatuan pertahanan keamanan, serta luas wilayah. 


\section{- DAFTAR PUSTAKA}

Zainuddin, A. (t.thn.). Diambil kembali dari id.scribd.com: id.scribd.com

Bariqbiyyu. (t.thn.). Diambil kembali dari id.scribd.com : id.scribd.com

kristina. (2021, november). Diambil kembali dari detik.com/edu/detikpedia/d-5831952/hakikatwawasan-nusantara: detik.com/edu/detikpedia/d-5831952/hakikat-wawasan-nusantara

randitriya, a. (t.thn.). Diambil kembali dari academia-edu/18781786/wawasan-nusantaraperwujudan-wawasan-nusantara-dalam-kehidupan-berbangsa-dan-bernegara-indonesia: academia-edu/18781786/wawasan-nusantara-perwujudan-wawasan-nusantara-dalamkehidupan-berbangsa-dan-bernegara-indonesia

RivaJepRut. (t.thn.). Diambil kembali dari id.scribd.com: id.scribd.com

(2015, mei ). Diambil kembali dari iptekindonesia.blogspot-com/2015/05/faktor-faktor-yangmempengaruhi-wawasan : iptekindonesia.blogspot-com/2015/05/faktor-faktor-yangmempengaruhi-wawasan

Attoriq, S., \& Sodik, M. A. (2018). Pencegahan Dan Pengendalian Infeksi Terkait Pelayanan Kesehatan Di Lahan Praktik. 